\title{
CHANGES OF ISOTOPIC COMPOSITION IN GASES EMITTED FROM WASTEWATER TREATMENT PLANT - PRELIMINARY STUDY
}

\author{
ZMIANY SKŁADU IZOTOPOWEGO GAZÓW EMITOWANYCH \\ Z OCZYSZCZALNI ŚCIEKÓW - BADANIA WSTĘPNE
}

\begin{abstract}
Investigations of processes occurring during wastewater treatment have progressed beyond the stage of technology. Currently, great numbers of representatives of diverse specialist research apply increasingly sophisticated measurement methods that have not been employed in this field of science. One of the methods is IRMS (Isotope Ratio Mass Spectrometry). Tracking changes in the ratios of biogenic element isotopes is useful in eg identification and monitoring of investigated processes. Since the IRMS technique has hardly been used for investigations of the wastewater treatment process, pilot research should be instigated to determine the isotope ratios occurring naturally in the process. The aim of the study was to determine changes in carbon and nitrogen isotope ratios at the successive stages of the technological line in wastewater treatment plants. The study material comprised: i) suspensions of raw sewage and mixtures of wastewater and activated sludge; ii) gases sampled from the volume of the suspensions; iii) gases sampled from the air above the suspension surface. The research material originated from the facilities of "Hajdow" municipal wastewater treatment plant in Lublin (SE Poland). The samples were analysed for the carbon and nitrogen isotope ratios, and the concentrations of the gases as well as total organic carbon (TOC), inorganic carbon (IC), Kjeldahl nitrogen (KN), dry weight, $\mathrm{pH}$, and Eh were determined. The results obtained suggest that: i) the IRMS technique can be successfully applied in investigations of processes occurring during wastewater treatment; ii) isotope ratios in the carbon and nitrogen compounds $\left(\mathrm{CO}_{2}\right.$ and $\mathrm{N}_{2}$ ) both in the suspensions and gases contained therein and in the air above them differ from each other and change at the different stages of the treatment process; iii) further research is indispensable in order to identify processes responsible for fractionation of carbon and nitrogen isotopes.
\end{abstract}

Keywords: IRMS, stable isotopes, wastewater, activated sludge, gas emission

Investigations of processes occurring during wastewater treatment have progressed beyond the stage of technology. The importance of development of new measurement methods or adjustment of existing techniques has been increasingly emphasised [1, 2]. Hence, investigations have been conducted to determine the broad range of wastewater and sludge properties, $e g$ the composition of biological communities identified in

\footnotetext{
${ }^{1}$ Institue of Agrophysics, Polish Academy of Science, ul. Doświadczalna 4, 20-290 Lublin, Poland

${ }^{2}$ Mass Spectrometry Laboratory, Institute of Physics, Maria Curie-Skłodowska University, pl. M. Curie-Skłodowskiej 1, 20-031 Lublin, Poland

Corresponding author: w.stelmach@ipan.lublin.pl
} 
the wastewater treatment plant [3-5], the structure of the communities [6-8], the mechanical properties of flocs [9-10], or the colour of sludge [11]. Important and widely discussed task in the area of wastewater treatment are the ways of physiological activity of activated sludge description, expressed by eg different types of OUR (Oxygen Uptake Rate) [12-14] and fractioning of the substrate for building and calibration of models of sewage treatment processes $e g$ models of ASM group [12, 14-17]. Investigations of the agricultural use of wastewater are equally important [18-21].

As it is visible above, mostly there are determined sewage parameters treated in the particular facilities of WWTP and properties of activated sludge. But for gases that are formed in treatment plant mainly odour nuisances are considered from the engineering and scientific point of view [22-24]. These problems are solved in most of cases by objects encapsulation and directing of the smelling gases through proper filters, $e g$ biofilters. Since a short time it is taken into consideration emission of greenhouse gases from WWTP $[25,26]$, and the possibility to valuate wastewater treatment process or quality of treated sewage basing on gaseous substances emitted from wastewater [27, 28].

One of the methods widely used in environmental studies other than analyses of the wastewater treatment process is the IRMS (Isotope Ratio Mass Spectrometry) technique [29-32]. It consists in separation of different isotopes in a constant, strong electromagnetic field, which allows determination of stable isotope ratios in a sample $\left(e g{ }^{13} \mathrm{C}\right.$ and ${ }^{12} \mathrm{C}$ as well as ${ }^{15} \mathrm{~N}$ and $\left.{ }^{14} \mathrm{~N}\right)$ [33].

Literature does not provide many papers on the application of the IRMS technique in analysis of wastewater treatment processes or, more broadly, investigations of the impact of wastewater on the environment. The few authors describing these issues should be mentioned: i) Ronkanen and Kløve [34], who investigated the process of wastewater treatment in peatlands; ii) Law et al [35], who quantified the proportion of $\mathrm{C}$ isotopes in raw sewage and subsequent distribution of the element after primary and secondary treatment processes; iii) Zvab Rozic et al [36], who used the IRMS technique to detect dispersal of pollution along the Adriatic Sea coast; iv) Morrissey et al [37], who used stable isotopes as indicators of the impact of wastewater on organisms inhabiting urban rivers; v) Lindehoff et al [38], who determined the effect of municipal sewage on the toxicity of selected algal species; or vi) Gammons et al [39], who focused on nitrogen and carbon transformations in a small watercourse, where municipal wastewater was discharged [34-39]. Yet, there are no reports presenting the values of stable isotope ratios for wastewater and/or sludge at different stages of treatment.

A comprehensive IRMS-based analysis of processes occurring in wastewater treatment plants necessitates assessment of the background, which in the context of the proposed research involves determination of isotope ratios at successive stages of the technological process in a wastewater treatment plant. The aim of this study was to perform a preliminary assessment of changes in the $\delta^{15} \mathrm{~N}$ and $\delta^{13} \mathrm{C}$ content in wastewater, sludge, and gases emitted into the atmosphere at subsequent stages of the technological system in a wastewater treatment plant. 


\section{Materials and methods}

\section{Wastewater samples and analyses}

Material for the analyses was sampled from technological system facilities at the mechanical-biological wastewater treatment plant "Hajdow", Lublin (central-eastern Poland), which removes carbon, nitrogen and phosphorus compounds with the average mean capacity of $65,000 \mathrm{~m}^{3} / \mathrm{d}$. Sanitary and industrial sewage from Lublin agglomeration are discharged to the wastewater treatment plant, where they are purified in the following facilities: bar screen primary sedimentation tanks - pumping stations - anaerobic chambers main bioreactors (for nitrification, denitrification and biological dephosphatation processes) - secondary sedimentation tanks. Biological part of WWTP is based on modified BARDENPHO system. The investigation was performed using gas and liquid samples.

Two types of gas samples were collected: the air above the chambers and gas emitted in the volume of the wastewater and activated sludge mixture. Gases from ambient air were sampled with a syringe, whose inlet was placed ca. $20 \mathrm{~cm}$ above the surface of the wastewater and activated sludge mixture. The gas was stored in gas-tight vessels. Gas released in the volume of the wastewater and activated sludge mixture was sampled by means of loaded chambers immersed upside down. Gases produced as a result of microbial activity moved in the sludge towards its surface and accumulated in the chambers, thereby forcing the chambers to emerge on the surface. The gases were sampled into gas-tight vessels with the use of a syringe. They were taken from the sludge at each of the below presented stages, except for the raw sewage (no possibility of sampling).

The liquid samples comprised raw wastewater entering the treatment plant and the sewage and activated sludge mixture. They were kept in $250 \mathrm{~cm}^{3}$ bottles.

The gas and liquid samples were taken at the same successive points of the following facilities of technological line:

1 - inlet - raw sewage;

2 - bioreactor: denitrification chamber I - wastewater and activated sludge;

3 - bioreactor: nitrification chamber I - wastewater and activated sludge;

4 - bioreactor: denitrification chamber II - wastewater and activated sludge;

5 - bioreactor: nitrification chamber II - wastewater and activated sludge;

6 - recirculate - thickened activated sludge.

The sampled mixtures of wastewater and activated sludge were well stirred and subjected to physico-chemical analyses in order to assess the content of total organic carbon, inorganic carbon (IC), Kjeldahl nitrogen, dry weight, $\mathrm{pH}$, and Eh.

TOC and IC were determined using an automated Shimadzu TOC-V CPH carbon analyser coupled with an SSM 5000 A attachment in accordance with manufacturer's instructions. KN was determined with the use of a Behr Labor-Technik instrument in accordance with the attached application note. The dry matter content was determined on the basis of the PN -EN 12879:2004 standard. The values of $\mathrm{pH}$ and Eh were determined with a Hach-Lange HQ 40D multi-measure device using electrodes Intellical PHC and Intellical ORP.

The dry weight (of the liquid samples) was analysed in order to determine the stabile carbon isotope ratios $\left({ }^{13} \mathrm{C}\right.$ relative to $\left.{ }^{12} \mathrm{C}\right)$ and nitrogen $\left({ }^{15} \mathrm{~N}\right.$ relative to $\left.{ }^{14} \mathrm{~N}\right)$. The sample preparation procedure was as follows: $8 \mathrm{mg}$ of dry weight (dried at $105^{\circ} \mathrm{C}$ ) was mixed with $1 \mathrm{~g}$ of copper oxide $(\mathrm{CuO})$ and ground in a mortar. Next, the mixture was placed in oxygen- 
purged glass tubes (pyrex glass) and a few chips of pure copper were added. The next step was tube-sinking with a gas burner and incineration in a furnace at a temperature of $560^{\circ} \mathrm{C}$ for 8 hours. Incinerated samples were purified under vacuum to remove water and other contaminants. The samples were analysed for the content of isotopes $\delta^{13} \mathrm{C}$ and $\delta^{15} \mathrm{~N}$ separately. The measurements were performed in the Mass Spectrometry Laboratory, Institute of Physics, Maria Curie-Skłodowska University, Lublin (Poland) using a triple-collector mass spectrometer with a dual-inlet system. The $\delta^{13} \mathrm{C}$ was measured according to PDB using NBS-22 and IA-R042 (powdered bovine liver), while the $\delta^{15} \mathrm{~N}$ using IA-R042. Atmospheric nitrogen was the standard for the nitrogen compounds. The standard uncertainty rate was $0.05 \%$.

The gas samples were assessed for the concentrations of $\mathrm{CO}_{2}, \mathrm{O}_{2}$, and $\mathrm{CH}_{4}$. The analysis was performed using a Shimadzu GC- 14A gas chromatograph equipped with a Thermo Conduction Detector (TCD) with helium as a carrier gas. The $\mathrm{CO}_{2}$ and $\mathrm{CH}_{4}$ concentrations were analysed using a steel column packed with Porapak Q, whereas the $\mathrm{O}_{2}$ concentration was assessed on a column packed with a molecular sieve $5 \mathrm{~A} .0 .1 \mathrm{~cm}^{3}$ of gas was loaded into the column each time.

Analysis of the carbon isotopic composition of carbon dioxide was performed in the gas samples using a stable isotope ratio mass spectrometer (IRMS - Isotope Ratio Mass Spectrometry) Thermo Electronics DELTA V Advantage with a continuous gas flow. $0.1 \mathrm{~cm}^{3}$ of gas was dispensed. The $\delta^{13} \mathrm{C}$ was measured according to PDB. The standard uncertainty rate was $0.05 \%$.

For the GC and IRMS analyses, the samples were dispensed using a syringe with a manual feeder (with a stop-valve) and a conically tipped $0.1 \mathrm{~cm}^{3}$ VICI needle with a side port, which prevented mixing the sampled gas with laboratory air.

All measurements (both physico-chemical analyses and stable isotope ratio assessment) were done in triplicate.

\section{Calculations and statistical analysis}

Isotope data are expressed in the $\delta$ notation defined as the relative difference between the isotope ratio in the sample and the standard. The $\delta X$ values are expressed as [40]:

$$
\delta X=\left(\left(R_{\text {sample }} / R_{\text {standard }}\right)-1\right) \cdot 1000[\% \text { o }]
$$

where: $X$ is ${ }^{13} \mathrm{C}$ or ${ }^{15} \mathrm{~N}, R_{\text {sample }}$ is the isotope ratio $\left({ }^{13} \mathrm{C} /{ }^{12} \mathrm{C}\right.$ or $\left.{ }^{15} \mathrm{~N} /{ }^{14} \mathrm{~N}\right)$ of the sample, and $R_{\text {standard }}$ is the isotope ratio $\left({ }^{13} \mathrm{C} /{ }^{12} \mathrm{C}\right.$ or ${ }^{15} \mathrm{~N} /{ }^{14} \mathrm{~N}$ ) of the standard (PDB-Pee Dee Bellemnite for $\mathrm{C}$, atmospheric $\mathrm{N}_{2}$ for $\mathrm{N}$ ) [41].

\section{Results and discussion}

The physico-chemical characteristics of the tested suspensions are presented in Table 1.

The values presented in Table 1 as well as the information provided by the technologist indicate that on the day of sampling the wastewater treatment plant worked without failure and purified the wastewater efficiently.

The concentrations of methane, carbon dioxide, and oxygen in the analysed gas samples are shown in Figures 1 and 2.

In the gases sampled from the volume of the wastewater and activated sludge mixture, methane was detected at all the sampling points, except for nitrification chamber I 
(sampling point 3). The highest concentration was recorded in the anaerobic denitrification chamber (sampling point 2).

The concentrations of carbon dioxide and oxygen in samples taken from the volume of the wastewater and activated sludge mixture were correlated with each other. The highest concentration of oxygen was noted in nitrification chamber I (sampling point 3), where the $\mathrm{CO}_{2}$ concentration was the lowest and no methane was detected. A relatively high concentration of oxygen $(8.52 \%)$ was recorded in nitrification chamber II. In the other samples, the oxygen concentration ranged from 2.47 to $5.46 \%$.

Table 1

Physicochemical characteristics of the suspensions at the successive sampling points

\begin{tabular}{|c|c|c|c|c|c|}
\hline Sampling point & $\begin{array}{c}\text { Dry mass } \\
{[\mathbf{g} / \mathbf{k g}]}\end{array}$ & $\mathbf{p H}$ & $\begin{array}{c}\mathbf{E h} \\
{[\mathbf{m V}]}\end{array}$ & $\begin{array}{c}\text { TOC } \\
{\left[\mathbf{g} / \mathbf{d m}^{\mathbf{3}}\right]}\end{array}$ & $\begin{array}{c}\mathbf{T K N} \\
{\left[\mathbf{g} / \mathbf{d m}^{\mathbf{3}}\right]}\end{array}$ \\
\hline 1 & 0.84 & 6.94 & -392.67 & 0.18 & 0.08 \\
\hline 2 & 2.52 & 6.93 & -305.50 & 0.29 & 0.27 \\
\hline 3 & 2.80 & 6.89 & -178.80 & 0.29 & 0.29 \\
\hline 4 & 2.88 & 6.85 & -227.00 & 0.32 & 0.29 \\
\hline 5 & 3.10 & 6.76 & -178.00 & 0.31 & 0.28 \\
\hline 6 & 6.55 & 6.71 & -218.00 & 0.50 & 0.63 \\
\hline
\end{tabular}

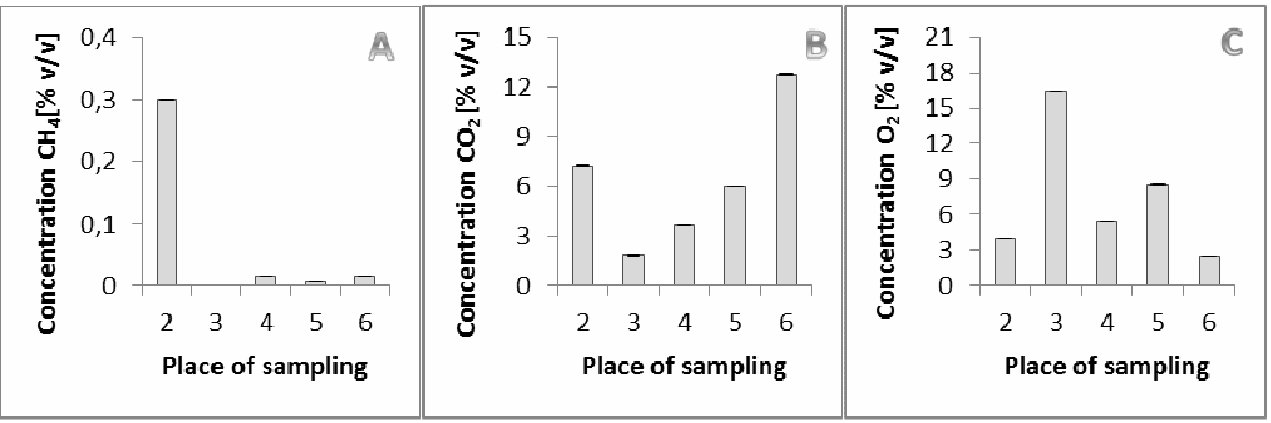

Fig. 1. Concentrations of methane (A), carbon dioxide (B) and oxygen (C) in gas samples emitted from the volume of the mixture of wastewater and activated sludge

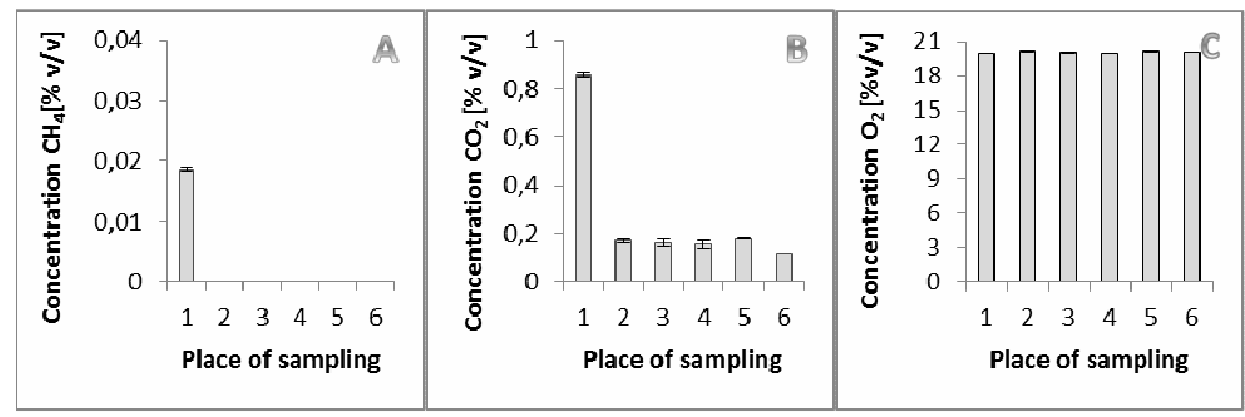

Fig. 2. Concentrations of methane (A), carbon dioxide (B) and oxygen (C) in air sampled above the suspension surface 
No gas sample taken from above the suspension surface (except for that taken at the inlet) contained methane (Fig. 2A). In the air samples taken above raw sewage, the $\mathrm{CH}_{4}$ concentration was approximately 100 fold higher than that in the ambient atmospheric air in this part of Europe, which currently is $1.8 \mathrm{ppm}$.

The concentration of carbon dioxide (Fig. 2B) in all the gas samples taken from headspace (except for the gases from above raw sewage) ranged from 0.12 to $0.18 \%$. The lowest concentration was noted above the recirculate (sampling point 6). The concentrations were several-fold higher than those in the ambient atmospheric air in this part of Europe. The concentration of $\mathrm{CO}_{2}$ above the surface of raw sewage (sampling point 1 ) was nearly 5 times higher than in the other sampling points and reached $0.86 \%$.

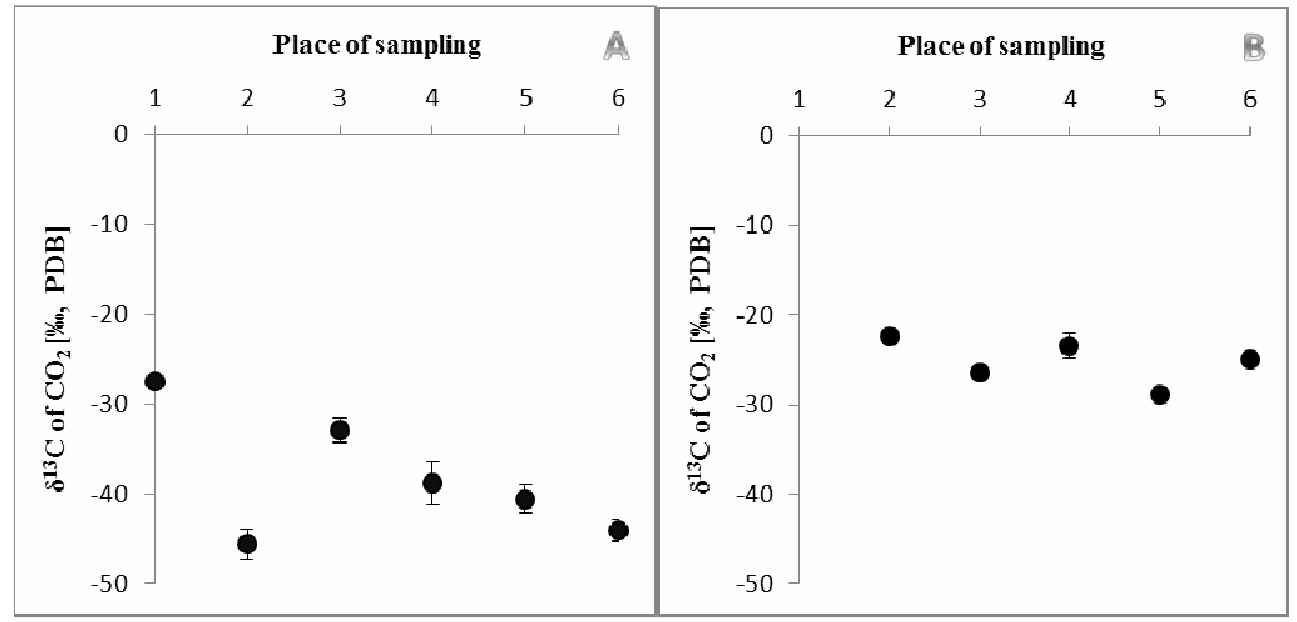

Fig. 3. $\quad \delta^{13} \mathrm{C}$ values for carbon dioxide in the successive sampling points. Graph $\mathrm{A}$ - gas sampled from the air above the suspension surface; B - gas samples from the volume of the wastewater and activated sludge mixture

The analyses of the carbon isotopic composition of $\mathrm{CO}_{2}$ revealed that all the samples had a lower content of the heavier isotope than $\mathrm{CO}_{2}$ contained in the atmospheric air from this region of Poland; at the height of $2 \mathrm{~m}$ above the ground, ambient $\delta^{13} \mathrm{C}$ of $\mathrm{CO}_{2}$ ranges from -7.56 to $-18.56 \%$ o depending on the time of the day [42]. Simultaneously, carbon dioxide in the samples taken from the air above the suspension (Fig. 3A) contained significantly lower amounts of the heavier $\mathrm{C}$ isotope than $\mathrm{CO}_{2}$ sampled from the volume of the wastewater and activated sludge mixture (Fig. 3B). The values of the carbon isotopes in $\mathrm{CO}_{2}$ from air sampled above the surface of the suspension at the various treatment stages ranged from -33 to $-46 \%$, whereas the range of the values of $\delta^{13} \mathrm{C}$ of $\mathrm{CO}_{2}$ in the air sampled from the volume of the wastewater and activated sludge mixture was narrower, ie -22 to $-29 \%$.

The values of $\delta^{13} \mathrm{C}$ of $\mathrm{CO}_{2}$ sampled from the volume of the wastewater and activated sludge mixture (Fig. 3B) exhibit certain regularity: $\mathrm{CO}_{2}$ emitted in the denitrification chambers (anaerobic conditions or limited oxygen availability - sampling points 2 and 4) contained higher quantities of isotope ${ }^{13} \mathrm{C}$ than in the nitrification chambers characterised by oxygen availability (sampling points 3 and 5). $\delta^{13} \mathrm{C}_{\text {of } \mathrm{CO}_{2}}$ in the recirculate (sampling point 
6) was increased, compared to the value obtained for nitrification chamber II, ie the content of the heavier isotope increased.

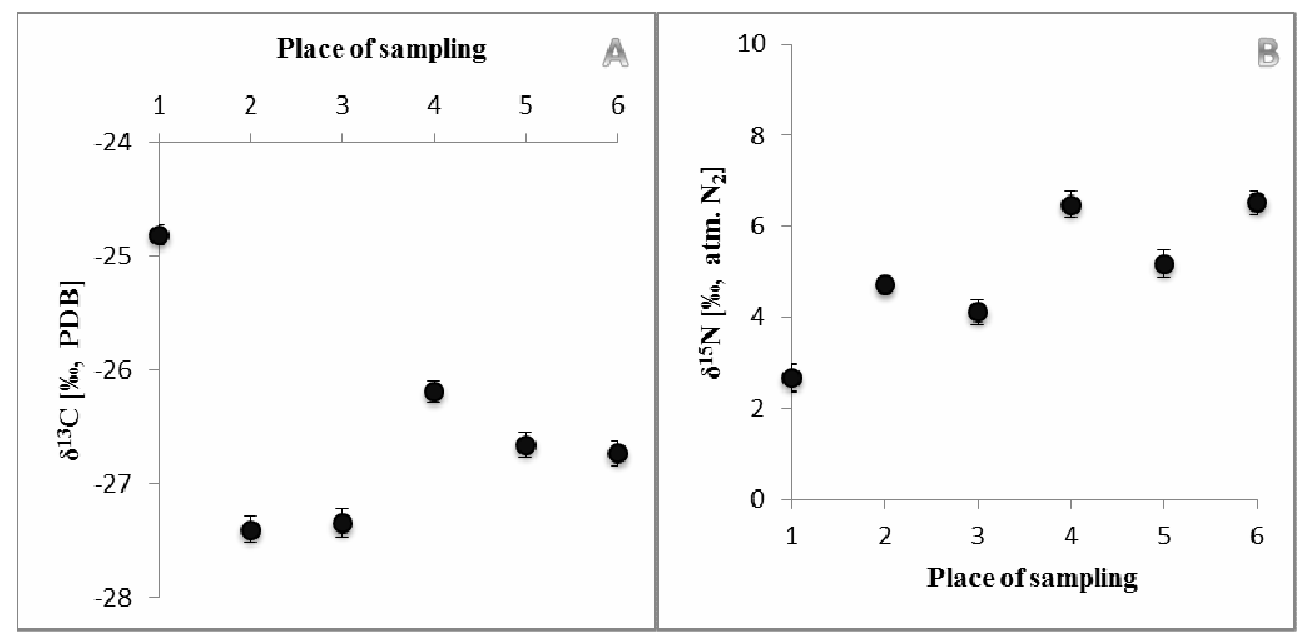

Fig. 4. Values of $\delta^{13} \mathrm{C}$ of carbon dioxide (A) and $\delta^{15} \mathrm{~N}$ of $\mathrm{N}_{2}(\mathrm{~B})$ for the dry weight of the sludge in the respective sampling points

The highest value of $\delta^{13} \mathrm{C}$ (hence, the highest content of the heavier isotope) in the solid samples (Fig. 4A) was noted in sampling point 1, ie prior to the treatment process. In the subsequent purification steps, substantial differences in the delta values are noticeable. It is worth noting that the values of $\delta^{13} \mathrm{C} \mathrm{CO}_{2}$ for the dry weight of sludge (Fig. 4A) are closer to the $\delta^{13} \mathrm{C} \mathrm{CO}_{2}$ values determined in gases sampled from the suspensions rather than to the $\delta^{13} \mathrm{C} \mathrm{CO}_{2}$ values recorded for gases collected above the suspension surface.

The analysis of the $\delta^{15} \mathrm{~N}$ values recorded at the successive stages of the wastewater treatment process shows a clearly increasing tendency for the $\delta^{15} \mathrm{~N}$ value (hence, an increase in content of the heavier ${ }^{15} \mathrm{~N}$ nitrogen). Additionally, the analysis of the successive processes (denitrification chamber $\rightarrow$ nitrification chamber $\rightarrow$ denitrification chamber $\rightarrow$ nitrification chamber; sampling points 2-5) reveals a similar relationship as in the case of carbon: the anaerobic conversion of the nitrogen compounds increased the content of the heavier ${ }^{15} \mathrm{~N}$ isotope, and the aerobic processes were accompanied by a decreased content of $\delta^{15} \mathrm{~N}$. This phenomenon may be related to the fractionation process or "mixing" of activated sludge from the different sampling points.

At this stage of the research, it is difficult to elucidate the course of carbon and nitrogen fractionation in the wastewater treatment process. As already mentioned, the present investigations are a preliminary step, and further research is indispensable to answer the question why deltas increase in some processes and decrease in others. However, occurrence of fractionation has already been confirmed. Therefore, one can claim that the IRMS technique can be successfully applied for analyses of purification processes.

Since we failed to find literature reports of the $\delta^{15} \mathrm{~N}$ and $\delta^{13} \mathrm{C}$ values for raw sewage or activated sludge, it was impossible to compare our results with literature data. 


\section{Conclusions}

1. The IRMS technique can be successfully used in investigations of processes occurring during sewage treatment.

2. The isotope ratios in carbon and nitrogen $\left(\mathrm{CO}_{2}\right.$ and $\left.\mathrm{N}_{2}\right)$ compounds in suspensions and gases contained therein as well as in the ambient air differ from each other and change in the respective stages of the purification process.

3. Further research is indispensable for identification of processes responsible for fractionation of carbon and nitrogen isotopes within facilities of WWTP.

\section{References}

[1] Malicki J, Montusiewicz A, Bieganowski A. Improvement of counting helminth eggs with internal standard. Water Res. 2001;35(9):2333-2335. DOI: 10.1016/S0043-1354(00)00517-0.

[2] Le NT, Julcour C, Ratsimba B, Delmas H. Improving sewage sludge ultrasonic pretreatment under pressure by changing initial pH. J Environ Manage. 2013;128:548-554. DOI: 10.1016/j.jenvman.2013.06.001.

[3] Puigagut J, Salvado H, Garcia J. Short-term harmful of ammonia nitrogen on activated sludge microfauna. Water Res. 2005;39:4397-4404. DOI:10.1016/j.watres.2005.08.008.

[4] Pérez-Uz B, Arregui L, Calvo P, Salvadó H, Fernández N, Rodrígeuz E, et al. Assessment of plausible bioindicators for plant performance in advanced wastewater treatment systems. Water Res. 2010;44(17):5059-5069. DOI:10.1016/j.watres.2010.07.024.

[5] Jaromin-Gleń K, Babko R, Łagód G, Sobczuk H. Community composition and abundance of protozoa under different concentration of nitrogen compounds at "Hajdow" wastewater treatment plant. Ecol Chem Eng S. 2013;20(1):127-139. DOI: 10.2478/eces-2013-0010.

[6] Jiang JG, Shen YF. Use of the aquatic protozoa to formulate a community biotic index for an urban water system. Sci Total Environ. 2005;346(1-3):99-111. DOI:10.1016/j.scitotenv.2004.12.001.

[7] Łagód G, Chomczyńska M, Montusiewicz A, Malicki J, Bieganowski A. The proposal of measurement and visualization methods for dominance structures in the saprobe communities. Ecol Chem Eng S. 2009;16(3):371-376.

[8] Babko R, Łagód G, Jaromin-Gleń K. Abundance and structure of ciliated protozoa community at the particular devices of "Hajdów" WWTP. Ann Set Environ Prot. 2012;14:56-68.

[9] Guellil A, Thomas F, Block J-C, Bersillon J-L, Ginestet P. Transfer of organic matter between wastewater and activated sludge flocs. Water Res. 2001; 35(1):143-150. DOI: 10.1016/S0043-1354(00)00240-2

[10] Bieganowski A, Łagód G, Ryżak M, Montusiewicz A, Chomczyńska M, Sochan A. Measurement of activated sludge particle diameters using laser diffraction method. Ecol Chem Eng S. 2012;19(4):597-608. DOI: 10.2478/v10216-011-0042-7.

[11] Yu RF, Chen HW, Cheng WP, Chu ML. Measurements of wastewater true color by 4/6 wavelength methods and artificial neural network. Environ Monit Assess. 2006;118(1-3):195-209. DOI: 10.1007/s10661-006-1491-9.

[12] Lagardea F, Tusseau-Vuillemina M, Lessardb P, Héduita P, Dutropa F, Mouchelc JM. Variability estimation of urban wastewater biodegradable fractions by respirometry. Water Res. 2005;39(19):4768-4778. DOI: 10.1016/j.watres.2005.08.026.

[13] Dulekgurgen E, Dogruel S, Karahan O, Orhon D. Size distribution of wastewater COD fractions as an index for biodegradability. Water Res. 2006;40(2):273-282. DOI: 10.1016/j.watres.2005.10.032.

[14] Pasztor I, Thury P, Pulai J. Chemical oxygen demand fractions of municipal wastewater for modeling of wastewater treatment. Intern J Environ Sci Technol. 2009;6(1):51-56. DOI: 10.1007/BF03326059.

[15] Vollertsen J, Hvitved-Jacobsen T. Biodegradability of wastewater - a method for COD-fractionation. Water Sci Technol. 2002;45(3):25-34.

[16] Mąkinia J. Performance prediction of full-scale biological nutrient removal systems using complex activated sludge models. - Veröffentlichungen des Institutes für Siedlungswasser-wirtschaft und Abfalltechnik der Universität Hannover. 2006; 136.

[17] Drewnowski J, Makinia J. Modeling hydrolysis of slowly biodegradable organic compounds in biological nutrient removal activated sludge systems. Water Sci Technol. 2013;67(9):2067-2074. DOI: 10.2166/wst.2013.092. 
[18] Ganoulis J. Risk analysis of wastewater reuse in agriculture. Intern J Recycling Organic Waste Agric. 2012;1(3):1-9. DOI: 10.1186/2251-7715-1-3.

[19] Wojcieszczuk T, Hammal O, Malinowski R, Wojcieszczuk M, Chorągwicki Ł. The activity of chemical components of light and heavy soil in Syria after use of municipal sewage sludge from Deir Ez Zor City. Soil Sci Ann. 2012;63(3): 43-48. DOI: 10.2478/v10239-012-0032-1.

[20] Nosalewicz M, Stępniewska Z, Nosalewicz A. Effect of soil moisture and temperature on $\mathrm{N}_{2} \mathrm{O}$ and $\mathrm{CO}_{2}$ concentrations in soil irrigated with purified wastewater. Int Agrophys. 2013;27(3):299-304. DOI: 10.2478/v10247-012-0098-3.

[21] Panahi Kordlaghari K, Nikeghbali Sisakht S, Saleh A. Soil chemical properties affected by application of treated municipal wastewater. Ann Biol Res. 2013;4(3):105-108.

[22] Gostelow P, Parsons SA, Stuetz RM. Odour measurements for sewage treatment works. Water Res. 2001;35(3):579-597. DOI: 10.1016/S0043-1354(00)00313-4.

[23] Stuetz RM, Fenner RA, Engin G. Assessment of odours from sewage treatment works by an electronic nose, $\mathrm{H}_{2} \mathrm{~S}$ analysis and olfactometry. Water Res. 1999;33(2)b:453-461. DOI: 10.1016/S0043-1354(98)00246-2.

[24] Onkal-Engin G, Demir I, Engin SN. Determination of the relationship between sewage odour and BOD by neural networks. Environ Model Softw. 2005;20(7):843-850. DOI: 10.1016/j.envsoft.2004.04.012.

[25] Gupta D, Sing SK. Greenhouse gas emissions from wastewater treatment plants: A case study of noida. J Water Sustain. 2012;2(2):131-139.

[26] Daelman MRJ, van Voorthuizen EM, van Dongen LGJM, Volcke EIP, van Loosdrecht MCM. Methane and nitrous oxide emissions from municipal wastewater treatment - results from a long-term study. Water Sci Technol. 2013;67(10):2350-2355. DOI: 10.2166/wst.2013.109.

[27] Stuetz RM, Fenner RA, Engin G. Characterisation of wastewater using an electronic nose. Water Res. 1999;33(2):442-452. DOI: 10.1016/S0043-1354(98)00245-0.

[28] Bourgeois W, Stuetz RM. Use of a chemical sensor array for detecting pollutants in domestic wastewater. Water Res. 2002;36(18):4505-4512. DOI: 10.1016/S0043-1354(02)00183-5.

[29] Baggs EM. A review of stable isotope techniques for $\mathrm{N}_{2} \mathrm{O}$ source partitioning in soils: recent progress, remaining challenges and future considerations. Rapid Commun Mass Spectrom. 2008;22(11):1664-1672. DOI: $10.1002 / \mathrm{rcm} .3456$.

[30] Kuzyakov Y. How to link soil $\mathrm{C}$ pools with $\mathrm{CO}_{2}$ fluxes? Biogeosciences. 2011;8(6):1523-1537. DOI: 10.5194/bg-8-1523-2011.

[31] Busari MA, Salako FK, Tuniz C, Zuppi GM, Stenni B, Adetunji MT, et al. Estimation of soil water evaporative loss after tillage operation using the stable isotope technique. Int Agrophys. 2013;27(3):257264. DOI: $10.2478 / v 10247-012-0093-8$.

[32] Szarlip P, Stelmach W, Jaromin-Glen K, Bieganowski A, Brzezinska M, Trembaczowski A, et al. Comparison of the dynamics of natural biodegradation of petrol and diesel oil in soil. Desal Water Treat. 2014;1-8. DOI: 10.1080/19443994.2014.883777.

[33] Muccio Z, Jackson GP. Isotope Ratio Mass Spectrometry. Analyst. 2009;134(2):213-22. DOI: 10.1039/b808232d.

[34] Ronkanen A-K, Kløve B. Use of stabile isotopes and tracers to detect preferential flow patterns in a peatland treating municipal wastewater. J Hydrol. 2007;347(3-4):418-429. DOI: 10.1016/j.jhydrol.2007.09.029.

[35] Law Y, Jacobsen GE, Smith AM, Yuan Z, Lant P. Fossil organic carbon in wastewater and its fate in treatment plants. Water Res. 2013;47(14):5270-5281. DOI: 10.1016/j.watres.2013.06.002.

[36] Zvab Rozic P, Dolenec T, Lojen S, Kniewald G, Doleneca M. Using stable nitrogen isotopes in Patella sp. to trace sewage-derived material in coastal ecosystems. Ecol Indic. 2014;36:224-230. DOI: 10.1016/j.ecolind.2013.07.023.

[37] Morrissey CA, Boldt A, Mapstone A, Newton J, Ormerod SJ. Stable isotopes as indicators of wastewater effects on the macroinvertebrates of urban rivers. Hydrobiologia. 2013;700(1):231-244. DOI: 10.1007/s10750-012-1233-7.

[38] Lindehoff E, Graneli E, Graneli W. Effect of tertiary sewage effluent additions on Prymnesium parvum cell toxicity and stable isotope ratios. Harmful Algae. 2009;8(2):247-253. DOI: 10.1016/j.hal.2008.06.004.

[39] Gammons CH, Babcock JN, Parker SR, Poulson SR. Diel cycling and stable isotopes of dissolved oxygen, dissolved inorganic carbon, and nitrogenous species in a stream receiving treated municipal sewage. Chemical Geology. 2011;283(1-2):44-55. DOI: 10.1016/j.chemgeo.2010.07.006.

[40] Schwartz E, Blazewicz S, Doucett R, Hungate BA, Hart SC, Dijkstra P. Natural abundance $\delta^{15} \mathrm{~N}$ and $\delta^{13} \mathrm{C}$ of DNA extracted from soil. Soil Biol Biochem. 2007;39:3101-3107. DOI: 10.1016/j.soilbio.2007.07.004. 
[41] Pollierer MM, Langel R, Scheu S, Maraun M. Compartmentalization of the soil animal food web as indicated by dual analysis of stable isotope ratios $\left({ }^{15} \mathrm{~N} /{ }^{14} \mathrm{~N}\right.$ and $\left.{ }^{13} \mathrm{C} /{ }^{12} \mathrm{C}\right)$. Soil Biol Biochem. 2009;41(6):1221-1226. DOI: 10.1016/j.soilbio.2009.03.002.

[42] Szaran J, Dudziak A, Trembaczowski A, Niezgoda H, Hałas S. Diurnal variations and vertical distribution of $\delta^{13} \mathrm{C}$, and concentration of atmospheric and soil $\mathrm{CO}_{2}$ in a meadow site, SE Poland. Geol Quart. 2005;49(2):135-144.

\title{
ZMIANY SKŁADU IZOTOPOWEGO GAZÓW EMITOWANYCH Z OCZYSZCZALNI ŚCIEKÓW - BADANIA WSTĘPNE
}

\author{
Instytut Agrofizyki im. B. Dobrzańskiego, Polska Akademia Nauk, Lublin, Polska \\ Zakład Spektrometrii Mas, Instytut Fizyki, Uniwersytet Marii Curie-Skłodowskiej, Lublin, Polska
}

\begin{abstract}
Abstrakt: Badania procesów zachodzących w trakcie oczyszczania ścieków dawno wyszły już poza fazę technologiczną. Obecnie zaobserwować można coraz większe grono przedstawicieli różnych specjalności wykorzystujących do badań coraz bardziej wyszukane metody pomiarowe, które do tej pory nie były wykorzystywane w tym obszarze. Jedną z takich metod jest IRMS (Isotope Ratio Mass Spectrometry). Śledzenie zmian stosunków izotopów pierwiastków biogenicznych jest przydane m.in. w identyfikacji i monitorowaniu badanych procesów. Ponieważ technika IRMS praktycznie nie była do tej pory wykorzystywana do badania procesu oczyszczania ścieków, dlatego niezbędne są pilotażowe badania pozwalające na wyznaczenie naturalnie występujących stosunków izotopowych w tym procesie. Celem pracy było określenie zmian stosunków izotopów węgla i azotu na wybranych stopniach ciągu technologicznego oczyszczalni ścieków. Materiał badawczy obejmował: i) zawiesiny ścieków surowych i mieszaniny ścieków i osadu czynnego, ii) próby gazów z objętości zawiesin; iii) próby gazów z powietrza sponad powierzchni zawiesin. Materiał badawczy pochodzi z miejskiej oczyszczalni ścieków „Hajdów” w Lublinie (SE Polska). Próbki analizowano pod kątem stosunków izotopów stabilnych węgla i azotu, stężeń gazów oraz zawartości całkowitego węgla organicznego (TOC), węgla nieorganicznego (IC), azotu Kjeldahla (KN), suchej masy, pH i Eh. Uzyskane wyniki sugerują, że: i) technika IRMS może być z powodzeniem stosowana w badaniach procesów zachodzących podczas oczyszczania ścieków, ii) stosunki izotopowe w związkach węgla i azotu $\left(\mathrm{CO}_{2}\right.$ i $\left.\mathrm{N}_{2}\right)$, zarówno w zawiesinach, jak i w zawartych w nich gazach oraz w powietrzu nad zawiesiną, różnią się od siebie i zmieniają się na różnych etapach procesu obróbki, iii), niezbędne są dalsze badania w celu określenia procesów odpowiedzialnych za frakcjonowania izotopów węgla i azotu.
\end{abstract}

Słowa kluczowe: IRMS, izotopy stabilne, ścieki, osad czynny, emisja gazów 